\title{
TWO ELEPHANT CALVES
}

\section{By David Syeldrick}

On 1st July, 1954, the labourers working at the new lodge site at Aruba dam in the Royal Tsavo National Park, reported having seen a lone elephant calf come down to drink and go off again on its own. On the 3rd July, while watching some elephants watering at the dam, I noticed a small elephant calf wandering about in an aimless fashion at the far end of the dam. This calf made no attempt to join the herd watering, although it must have been aware of their presence, as they were making a considerable noise. After about twenty minutes the herd moved off, and the calf remained at the water's edge. This was obviously the same calf that had been seen by the labourers two days before. The surrounding country was extremely dry and there were several lions in the area, so I felt his chances of survival were pretty remote if left to his own devices. I decided, therefore, to capture him and try to rear him in captivity.

After a bit of a struggle, the baby was eventually subdued with the help of several labourers from the lodge. He was then taken to the main gate at Voi, where the ticket office was hastily converted into a stable. 'Two rangers were detailed to take charge of him and remain with him throughout the night. He was extremely aggressive at this stage and would charge anyone who entered the stable. He was fed on young maize plants through the window and got through a huge quantity the first night. The following morning a determined effort was made to tame him. As soon as he charged I punched him on the head and smacked his trunk. 'This puzzled him considerably and had the effect of making him back to the opposite end of the room. I then tried to approach and offer him some food, only to be charged again; so he received another punch on the head. After several attempts to crush me against the wall, he eventually calmed down and started cating the maize stalks offered him. As soon as one of the rangers entered the room, however, he became worried, and would try to charge. All the Africans were extremely frightened of him and I had the utmost difficulty in getting them to stand their ground. Nevertheless they soon got the form, taking it in turns to feed him and smack his trunk when he became obstreperous. We got him completely tame by 4 p.m. that afternoon.

An attempt was made to make him take milk (one part Ideal to two parts water) from a bottle, but without success. Neither 
could he be persuaded to take maize meal gruel or ugali. The only food he took any interest in was green leaves of various sorts. A great variety of green bush was provided and a note made of the different kinds selected. These were then collected in quantity and fed to him regularly.

After a weck he was transferred to new quarters behind the warden's house. This consisted of a stable 10 feet by 14 feet, with a concrete floor and makuti roof, the door leading into a paddock, containing a shady tree, water and a mud wallow. A tent was pitched next to the stable to accommodate two rangers. By this time he had calmed down completely and would follow the rangers detailed to look after him.

Samson, as he is now called, has become very attached to 'sumans and does not like being left alone. Should he lag behind when out feeding, he will break into a run to catch up.

On the 2nd August, 1954, I again visited Aruba dam. The labourers working on the lodge pointed out a young elephant calf on the other side of the dam and told me that it had been there all day. There were no other elephants in sight and no elephant had been down to drink that day. I hurriedly collected some labourers and approached the young calf with the object of capturing it. As soon as it saw us, it started to run away, but fell over and lay on the ground bellowing. It turned out to be a female of about the same age as the calf Samson captured a month before. She was obviously half starved and very weak.

She was taken back to Voi and placed in a paddock with Samson. Immediately she saw him she charged and started pushing him round the paddock. He put up with this for a bit and then retaliated and nearly knocked her over. After this, she secmed to realize there was nothing to be gained by being unfriendly, and slowly walked up to Samson, raised her trunk and touched him on the head and then started to feed next to him. Since then they have been on the best of terms.

While trying to persuade her to enter the stable at dusk, she again fell over and lay on the ground. She appeared to be completely exhausted and I began to fear she had been on her own too long and would not survive the first night. However, we raised her off the ground and placed her on her feet; she staggered a feiw yards and then stood with her fect apart, looking very misernble. After a few minutes she started to feed, so we left her in peace. She was visited several times during the night and cach time was seen to be feeding stcadily. 
The next morning she was let out into the paddock. She had recovered in a remarkable fashion and seemed full of life. Both calves were kept in the paddock all day, in order to get used to people. She was fed on green bush, acacia seed pods and oranges. The next day, two days after her capture, she and Samson were taken out to browse on the green bush at the base of Mazinga hill. She made no attempt to run away, but became alarmed at any sudden movement or the sound of cars. Since then "Fatuma" has settled down completely and might have been in captivity all her life. 